\title{
Mathematics and Puppet Play as a Method in the Preschool Teacher Education
}

\author{
Mirella Forsberg Ahlcrona, Ann Östman \\ University Väst, Trollhättan, Sweden \\ Email: mirella.forsberg-ahlcrona@hv.se
}

How to cite this paper: Forsberg Ahlcrona, M., \& Östman, A. (2018). Mathematics and Puppet Play as a Method in the Preschool Teacher Education. Creative Education, 9, 1536-1550. https://doi.org/10.4236/ce.2018.910113

Received: April 7, 2018

Accepted: August 4, 2018

Published: August 7, 2018

Copyright $\odot 2018$ by authors and Scientific Research Publishing Inc. This work is licensed under the Creative Commons Attribution International License (CC BY 4.0).

http://creativecommons.org/licenses/by/4.0/

(c) (i) Open Access

\begin{abstract}
This study explores students' perceptions and understanding of mathematics as a subject and using aesthetic expressions in their own mathematics teaching in preschool, more specifically, with puppet play as a method. In all teacher education in Sweden, mathematics in preschool is taught in different ways, which means that the teaching about the aesthetic possibilities as a part of the teaching of mathematics in preschool varies. The main purpose of the study has been to investigate students' mathematical development in preschool practice based on the changes made in the educational and methodological implications during teacher education. The data collection consists of texts from 73 students. The qualitative content analysis focuses on the students' descriptions of understanding and meaning of mathematics and aesthetics in their own teaching with the children. The results show that the methodological implications in the course's organization and structure enabled a variation of qualitative changes in the students perceptions and beliefs about mathematics and aesthetics, but also that the conceptual languages of mathematics could be varied and concretized by new methodological strategies.
\end{abstract}

\section{Keywords}

Teacher Education, Mathematics, Puppet Play, Preschool Education

\section{Introduction and the Research Question}

The curriculum for preschool in Sweden-Swedish National Agency for Education (Lpfö98/2010), specified basic mathematics as a particular area and a goal for children's development and learning. The content of mathematics in preschool is described both as a subject and as a way of developing children's abilities and skills to make use of mathematical thinking in different contexts. Preschool teacher education in Sweden is 3, 5 years long and often refers to methods 
that according to the preschool's educational tradition, means learning through different aesthetic expression and activities. That means a way of working through the playful, investigative and creative learning processes (Björklund, 2010; Carruthers \& Worthington, 2011; Forsberg Ahlcrona \& Pramling Samuelsson, 2014; Lundström, 2015).

Around the country future preschool teachers study mathematics based on local various curricula of the university, which in practice means that the extent, structure, content and methods vary. This also varies educational strategies to supply and develop student's ability of an approach that consciously encourage children's different ways of learning, understanding and using mathematics in everyday life. In our university the "Children's early mathematics learning" is a ten-week long course placed in the second year. Besides theoretical knowledge the students have also been given the opportunities to practice aesthetic activities as a way to develop creative ability and didactic skills in mathematics.

During the course introduction, several students usually express a negative attitude towards mathematics and the combination including manufacturing and use of puppets. For example: Never generally been interested in mathematics or aesthetics... Do not think mathematics and aesthetics are a good combination... Really mathematics is difficult for children and I guess it's hard to get their attention with just a puppet... The majority of the students also describe a self-image according to which they do not perceive themselves as mathematical or do not see mathematics as a general human ability to handle their everyday life (Ginsburg, Lee, \& Boyd, 2008; Lundin, 2008; Palmer, 2011). Initially, this study began as a reflection on students' attitudes and beliefs about mathematics as a subject, the meaning of mathematics in early childhood education but also reflection on a clearly expressed mistrust when it comes to aesthetic in the mathematics education-more specifically the puppet play as a method.

This study investigates how students perceive and express both knowledge and experience of aesthetic dimensions in mathematics and mathematical structure of aesthetics in their own practice. Research hypothesis is that the changes made in the course educational strategies and methodological implications, creates learning variation and conditions for the students' individual mathematical development. Thus, the research question of the study is as following: How do students understand and describe their mathematical communication with children based on their own aesthetic experiences?

\subsection{Theoretical Perspective}

The overall theoretical basis of the study is variation theory with elements of the phenomenological approach and developmental pedagogy. Variation theory is about capturing and visualizing variations in people's learning based on assumptions that learning involves changes in the way of distinguishing and experiencing their world (Marton \& Tsui, 2004). Variation theory's basic thoughts have evolved from phenomenology (Marton, 1981) and this approach investigates 
how perceptions and understandings relate to each other and to the investigated phenomenon (Marton \& Booth, 1997; Marton \& Pang, 2006). The didactic perspective of mathematics in the theoretical part of the course "Children's early mathematics learning" is treated as a phenomenon through variation of theoretical concepts.

The first concept used, the concept of the learning object consists of two aspects: a specific content that children should learn about, for example, numbers, and partly the abilities or skills that children are expected to develop, for example counting. The second concept used, the teaching act, comes from developmental pedagogy (Pramling, 1990, 1996) initially based on a phenomenological perspective, including theoretical assumptions by emphasizing the importance of diversity for children's learning and development. The learning act means that the child is expected to understand and develop knowledge by varying different ways of learning the object of the learning. The phenomenological perspective explores what learning means, namely the individual's experiences and perceptions, while the theory of variation explores how learning occurs, that is, based on variation in the content and structure of the learning. Marton and Tsui (2004) describe their respective perspectives in terms of "the space of learning" and "creating a space", meaning that learning takes place when the participants create, distinguish and visualize new dimensions of variation.

This study explores the variation of qualitative changes in the students' perceptions and notions of mathematics and aesthetics as phenomena in their own pedagogical practice. In order for the individual to develop understanding of a phenomenon, Marton and Tsui (2004) argue that it also assumes that the world of experience is expanded. In the course of "Children's early mathematics learning" this expansion of experience means that students are given the opportunity to work with and study the aesthetic dimensions of mathematics but alsoto experience the mathematical structure of aesthetics (Lindström, 2002; Sandahl, 2010).

\subsection{Mathematic in Preschool Education}

Early childhood mathematics education depends on the age of the children and the educational system of their country but also an engaging and encouraging learning environments creating by professional teachers (Lee, 2005; Lee \& Ginsburg, 2007; Zacharos, Antonopoulos, \& Ravanis, 2011). Children's mathematical learning in preschool is considered as important for the later development of elemental mathematics, no matter what theoretical perspective researchers choose to assume (Björklund \& Pramling, 2014; Clements \& Sarama, 2007; Cross, Woods, \& Schweingrber, 2009; Ginsburg \& Amit, 2008; Sarama \& Clements, 2009). Many research studies express that children should develop their ability to use mathematics to investigate, reflect on and try out different solutions of their own and others' issues (Charlesworth \& Leali, 2012; Nikiforidou \& Pange, 2010). Furthermore, they should be given the opportunity to develop 
their ability to explore, distinguish, express, and use mathematical concepts and relationships between concepts but also to develop their mathematical ability by bringing and following reasoning (Artut, 2015; Aslan \& Arnas, 2007; Elia \& Gagatsis, 2003). The further development of methodological aspects that contribute to the diversity of children's mathematical experiences in preschool is an important area to be explored and discussed (MacDonald, 2012; Pavlovičová \& Švecová, 2011). Against this background, this article can be considered as a methodological contribution in the field of teacher education and mathematics in preschool practice.

\section{3. "Children's Early Mathematics Learning" Content and Structure}

In the first part of the course, the teaching is focused on early childhood mathematics development and consists of lectures, literature seminars and group assignments. The students deepen theoretically in mathematical areas that correspond to those listed in the preschool's current curriculum: Numbers and Quantity, Patterns and Statistics, Time and Measurement, Room Perception, Shape and Geometry (Lpfö98/2010).

In the second part of the course, students are assigned one of these areas and then have to formulate a mathematical learning object. This part of the course includes two different workshops with theoretical and practical elements that treat the mathematical areas through different aesthetic expressions. In the third part of the course, the students work with the children during a two-week preschool practice period. The basic starting point for teaching the children is the student's individual planning based on its own mathematical, didactic and aesthetic knowledge and experience. The students are advised to complete three to five teaching sessions/activities. After the completed teaching, the chosen learning object is analyzed and discussed in relation to what the intentional learning object was, what is actually staged and what ultimately becomes the children's learned learning object (Wernberg, 2009). A robot puppet that the students make to introduce and implement their chosen learning object, is used as a didactic tool.

\subsection{Puppet Play and Puppet as a Tool}

Research about the puppets possibilities in teaching has, over time, identified varying forms of puppet play. The forms show a specific use of the puppet and in different ways describe how the puppet encourage children to develop their communicative skills-both in interaction with the puppet and with each other (Bernier \& O'Hare, 2005; Forsberg Ahlcrona, 2012; Hunt \& Renfro, 1982). In this study, puppet play refers to a collective term for several forms of play, either when the puppet is used in a planned way or spontaneous way in communicating with the children. Below is a brief presentation of various way of using and playing with puppets according to Hunt \& Renfro (1982: p. 19): 
Puppet play-happens spontaneously without teacher's involvement. One condition is that there are several and different puppets that children can use and play with.

Puppetizing-in this form, the teacher actively contributes with own knowledge about puppets and play techniques by guiding children in their attempt to present songs or short stories.

Puppet telling-means that the teacher uses puppets to dramatize, create and offer literary and musical experiences.

Puppet talking - the teacher uses the puppet to encourage children to talk and converse about their thoughts and experiences.

Puppet teaching-the task of the puppet is to raise the children's interest in something specific that the teacher wants to develop knowledge about or understanding for.

In this study students could choose and use different ways of puppet play as a support to create their own planning activities.

According to Brédikyté (2000), the use of different forms of puppet play in teaching enables various ways to be involved in linguistic and social interaction, both for children and for teachers. Her study shows that puppet play as a method in preschool contributes to the development of children's own expressive skills, the ability to imagine and their imagination. For example, when two children play with puppets they both pretend to be someone else. Such situations enable children to investigate, discover and develop new dimensions in their interaction with others and establish unusual contexts in mutual communication (Duffy, 2006; Hendy \& Toon, 2001). Harris (2000) stresses that children's play has a potential to create a way to imagine content and events that the child itself has usually not experienced earlier. The didactic perspective of the use of the play as a part of the preschool's mathematical learning environments means that children offered the opportunity to express their mathematical curiosity, but also get involved in mathematical activities and contexts initiated by teachers (Forsberg Ahlcrona \& Pramling Samuelsson, 2014). An educational environment that includes the use of puppet play can enable children to participate in dynamic interaction and communication-this through various aesthetic forms such as art, singing, dance and drama. In such interactions children can experience, learn and also become aware of different mathematical dimensions-shape, size, number, direction, quantity, measurement and time. As a part of the preschools communicative practice, puppet play can contribute to shape associations and memory which can be considered as a form of social and cultural experience (Bruner, 1990; Säljö, 2005; Wertsch, 2002).

\section{Method and Methodology}

This study investigates how students perceive their mathematical communication with children based on their own aesthetic experiences but also in which way the content of the workshops and seminars creates the conditions for the 
students' individual tasks with the puppet as a tool. The students were divided into groups about 20 persons, partly to be able to practice some moments several times and partly to have opportunities to discuss the task with each other and with the teacher.

First workshop: manufacturing the robot puppet and the technique of play

All puppets were made from the same material kit consisting of two body parts in foamed plastic which were assembled with the help of different details and one rod. Finished, the robot became about $40 \mathrm{~cm}$ high. The body of the robot was decorated according to what could mediate a specific mathematical message, for example with numbers, shapes or patterns. After the robot was made the play technique exercises followed behind the stage. That means using the puppet from the performing perspective, when only the robot is visible. The play technique and rules were practiced in combination with the puppets talking, singing and dancing as different ways of communicating. During the group exercises, students could discover the structure of mathematics when they divided the content of the text by number of players, counted dance steps and movement figures, and created different choreographic combinations based on rhymes and jingles, songs and music. In this workshop the focus was on play technology, that is, what the puppet can do and show for the children by itself.

Second workshop: developing and expanding the robots communicative skills

This workshop focused on what the student could accomplish with the robot by playing visibly. That means to use the puppet from a participating perspective when both the robot and the player is visible. The robot was "programmed" with features that invite and induce children's curiosity and mathematical thinking. For example: how the robot can sound-exercises with variations in voice interpretation that are sounds in different tone modes and forces; use the body like stamping, patching, snapping and sampled as sound effects; using instruments and other materials to make the impression stronger. In addition, the students practiced to create their own layout focusing on different mathematical concepts and content that could generate mathematical questions and dialogues with the robot. Special exercises were devoted to phrases, stresses between pulse/pace, rhythm, language rhythm, dynamics, pitch and pause that makes the robot appear as a machine. Discussion about a possible relationship the robot could have with the children and in which way and how it could be introduced, was based on the different suggestions of the group and with the teacher.

Seminar. The students were offered seminars afterwards on two occasions-the first one prior to their two-week preschool practice and the other one as a feedback, but also as a way to talk about their experiences before the examining task was submitted. In seminar form, students had the opportunity to discuss their planning with other students and with the teacher. To participate in the seminar a written text was required to be sent in advance, and shared with the group. Conversations about the texts were made in groups of four to six students according to the given headings: Children's Intended Learning Object, Purpose and Didactic Approach, My Own Precise Learning Object, Completed 
Teaching and Didactic Approach, and Discussion.

\section{Data Production and Analysis}

The collected data consists of the students' written assignments which are also part of the course's examining parts. A total of 73 student texts that passed were analyzed. In accordance with the ethical guidelines for research, stated by the Swedish Research Council, all participants were informed and asked for permission. In terms of confidentiality, all participants in the study were guaranteed anonymity and eventually names would be fictive, though events and utterances are authentic.

The students' written assignments are considered here as qualitative data bases consisting of two parts-a planning before the assignment was completed and the description of how the assignment was actually conducted-where the students also evaluated, reasoned and reflected on their mathematical area and the use of the puppet. The whole process can be summarized as follows:

1) Designing a learning object based on an assigned mathematical area,

2) Planning the content of a learning act including the use of a robot puppet and,

3) Distinguishing through documentation their own and the children's mathematical learning.

The focus of the analysis in the study is directed against the contents of the discussion section of the completed assignment. According to Linell (1994, 1998), the language plays an important role in qualitative research and especially in the analysis of texts of various kinds. The meaning of the analysis of the students' texts was to identify their perceptions and capture variation in descriptions of experiences generated in the concrete activities with the children (Marton \& Tsui, 2004). According Linell (1994) the language is influenced by tools when they are included in the communication:

"Artifacts are also typical 'boundary objects' connecting contexts and situations. They can be moved between situations, they bring along cultural knowledge, but they also acquire different meanings in different contexts, different for, say, experts and novices... Artifacts are not only or always what they seem to be designed for." (p. 347-348).

Because the puppet participated in the activities of all students, the analysis is also aimed on identifying how the students describe the puppet as a third party in their own interaction with the children.

The study's analysis was conducted in three steps: first, both parts of each work were read-the planned planning and then the implementation part-to be able to follow the description of the task's process and the involvement of the puppet. As the second step, positive and negative expressions were separated from the content in order to find differences and similarities within the respective themes. Finally, as the third step, descriptions of the students' perceptions and conclusions could be summarized under representative headings that also 
answer the research question of the study.

\section{Results}

\subsection{Perceptions about the Mathematics as a Subject Express Changes}

When the students describe how they look at the course task based on different experiences, they compare indirectly how they perceived mathematics earlier and how they perceived it based on the new insights.

"At first glance, mathematics can seem to be a heavy and difficult subject, but by including aesthetics into learning, an interest from the children is created, as aesthetics and mathematics evolve side by side through learning opportunities."

"Mathematics itself can be very boring. Sometimes I wonder if teachers know how much mathematics is used in everyday life and how to use it in a fun way. Many teachers do not use anything aesthetically appealing at all." "It was very rewarding to work with mathematics in preschool. At the start of the course, I can honestly say I did not believe this, and I did not think this would change, but I made it. I feel happy and want to immerse myself in this."

The image of their own mathematical change appears through the student's descriptions of contrasts on what they believed that mathematics was in general, mostly based on their previous school experiences. Another contributing factor to the change was the children's response and commitment as well as the sense of success when they managed to conduct their planned activities.

"I have learned to see mathematics as a subject that can be mixed with other subjects, thus gaining a deeper understanding of mathematics. I have never thought so before."

"The children's interest and dedication have been incredibly obvious throughout all the activities I did, but they have also continued to teach the robot more about quantification on their own initiative. They have made drawings with numbers, written letters to the robot, asked a lot of questions and reasoned with each other and with me."

"At first, I was very critical and did not think at all that it would be possible to teach the children in my group mathematics, as they are of younger age. But now I feel that my approach to both mathematics itself and to the children's knowledge and ability to develop, has been expanded."

Perceptions about the children's abilities to learn mathematic were often linked to the age of children as a pre-thought difficulty-the children were too young, or the assigned mathematical area was too advanced for their current group of children. There were also reflections about if the aesthetic elements could possibly make imbalances between the fun and the serious-if the puppet became so exciting that mathematics as subject would end up in the shadow? Or 
will the robot or the learning object catch their attention? Thus, mathematics was perceived as content with a given seriousness, and the including aesthetic expressions could possibly affect the level of seriousness.

\subsection{The Puppet Is Perceived as Support and Inspiration}

The puppet as a tool embodied the meaning of the assigned task and the purpose of the activity. The robots' identity was framed by the intended learning object, but the variation of the fictional identities and the purposes of using of the puppet was broad. The robot was the one who would teach the children or be the one to learn. Mostly it needed help to solve different problems.

"I was skeptical about the puppet before, because I did not really understand the purpose of it. Now, afterwards, I know that the puppet made the information more exciting for the children-it was the robot that should learn and needed help. The puppet contributed to an enthusiasm for the teaching and the tasks that can be hard to find otherwise. As for the aesthetics, I think it contributes to making mathematical education more interesting and alive."

The students describe that they experienced the meaning of playful learning because the children were overall positive, curious and active. This perceived response strengthened the student's involvement and led to a mutual confirmation and achievement. The robot was mainly used by a participating perspective and with elements of single performance when new events or assignments to the children were introduced.

"The puppet as a mathematical tool, I felt, made the children have a fun and playful learning. They were very excited about the robot and talked a lot about it on other occasions, and at home according to their parents. Some children even made their own robot and we have talked a lot about the robot Nexus's shapes and patterns that it had on its body."

"To me, it was a new experience to use a rod puppet as an educational tool. I could not but marvel at how the puppet caught the interests of the children, even though I'm not a skilled player and was quite unsure how I could use it in the best way. Their interest and dedication gave her a life."

Several students expressed surprise at the puppets positive reception. There was even concern among some that the children would not take it seriously because it was obvious that the robot was "not for real" but also because they felt uncertain themselves in the role of being players. Nevertheless, the students could inspire the children in various ways and encourage their participation.

\subsection{The Importance of Targeted and Creative Teaching}

It is obvious in all the texts that the task's planning structure helped the students to be targeted in their activities and that there was both an educational and a didactic overview of the process. It does not mean that there were no improvisa- 
tions and detours to come to the intended mathematical event. Both the openness for the children's proposals and changed plans appeared in the documentation which most often included a journal, filmed sequences, photos and sound recording.

"Once in the library, I read the message that the robot sent and showed the pictures that he had attached to his message. There were pictures on the small spherical planet the robot came from and pictures on the robot when he visited different places. In the chat, the robot answered both on what the children asked and told the first time and he answered their questions and also formulated a task for the children. The task was that the children would photograph different shapes-circles, rectangles, squares and triangles and send to the robot so that he could use these to refuel his spaceship."

"What I learned this period is that it does not always look as it was imagined from the beginning. I also realized the effect and impact the robot had on the children, how they wanted to help and that they developed along with the robot M2. I have also reflected on how important it is to ensure the purpose of use, why I do this and what do I want the puppet/activity to convey? It is also about having a creative and didactic approach in the use of an educational tool or in an activity."

"During the practice, several mathematical areas were covered in different ways, making me aware of that mathematics is something we communicate more or less all the time. Thus, it is important to use mathematical concepts in everyday life even if the children have not yet understood all expressions so they become acquainted with these and the an understanding can be developed."

In their reflections, the students deepened their understanding of the different ways in which using the puppet contributes to the motivation and intention of the children to speak and act mathematically, but also how the puppet as a tool contributes to the development of the preschool's learning environment. Most students express that in their coming professional teacher role they will use and develop other areas with the help of the puppet but, above all, consider the importance of structured planning and a creative didactic approach. The students' reflections also indicate that the children spontaneously use new mathematical concepts in other contexts and in the play, after the students had introduced and processed these in their planned activities.

\section{Discussion and Conclusion}

\subsection{Variation of Thinking about Mathematics}

The theoretical foundation of the course is in a variation theory (Marton \& Tsui, 2004; Marton \& Pang, 2006). This means that in this course children's variation of experiencing mathematics is made to a subject of the teacher education and offers the students the opportunity to explore the variety of teaching. Thus, the students should demonstrate the knowledge of how playing and aesthetic ex- 
pressions can be integrated into mathematics teaching.

The result shows that the course's structure enabled variations of qualitative changes in the student perceptions and notions of mathematics and aesthetics, but also that the conceptual language of mathematics could be varied and concretized (Forsberg Ahlcrona \& Pramling Samuelsson, 2014). The first part of the course contributed to the development of students' theoretical knowledge by treating children's mathematical thinking based on a broader view of how children spontaneously and intentionally, pay attention to, understand, examine and learn mathematics in everyday life (Björklund, 2010; Carruthers \& Worthington, 2011; Lundström, 2015). In the description of their own mathematical change the students often refer to the workshops as important to their expanded knowledge, with commenting that mathematics is "actually interesting" but also that mathematics was much more than they thought before. The majority of the students expressed explicitly that their confidence in their own mathematical ability had improved and increased throughout the course, and that their knowledge and mathematical skills had evolved. For example, during the workshops when the students compared how they intended to concretize their learning objects within the same mathematical field. Discussions were not just about how the students were thinking but also as much, why they were thinking as they did and what opportunities this variation could offer children's mathematical thinking and learning. These occasions also acted as a form of collective learning-to inspire each other with different mathematical suggestions based on a common purpose.

In his critical study of the elementary school mathematics, Lundin (2008) argues that mathematics education is not about mathematics itself but about a constructed picture of school mathematics that few students in practice can relate to. Furthermore, Lundin points out that the education gives many students experiences of a personal failure to understand and apply mathematics, which we consider to be expressed in different ways by the students during the course's introduction. According to Palmer (2011), the consequences of not being considered mathematical mean that the mathematics education of the preschool rarely aims to expand the children's intuitive mathematical interest, thinking and curiosity. Instead, the teachers, usually unconsciously, convey their own perceptions of school mathematics. Lee and Ginsburg (2007) found that the preschool teachers tend to believe that mathematics learning should not be highly demanding, nor should be implemented as instructional practices. Our conclusion, according to presented research and the study's results, is that preschool teacher education should develop and challenge student's experiences which address mathematics knowledge as well as mathematical education and practice.

\subsection{Increased Interest in Using the Puppet in Mathematics}

Attending mathematics through various aesthetic expressions was initially met by the students more or less pronounced suspicion because it was "two completely different things". Dance and art could be used as a support for mathe- 
matics, but the puppet and puppet play were not perceived as something with mathematical potential. The students' suspicion and uncertainty regarding the use of the puppet in the teaching are probably based on an idea that there is, in generally, no difference between puppet play and puppet theater (Bernier \& O'Hare, 2005). Puppet theater as an independent art form is usually associated with a very special "puppet interest" and practical talent. When puppet play as a method was introduced in the course, both theoretically and practically, the goal was to de-dramatize the puppet by emphasizing that the puppets use in puppet play is mostly based on didactic and educational issues. It is apparent from the results that the students both developed an understanding and perceived that the use of the puppet can contribute to the motivation and intent of children to speak and act mathematically.

In comparison with other artefacts, the puppet is special because it acts as if it were a speaking and thinking being. A puppet as a tool is a material object in which specific movements are incorporated, but not actions or goals relating to the use of the puppet. In practice, this means that one and the same puppet can have different personalities and different meanings, different properties, depending on who "fills" it with meaning and in what context this is done. In this study the students have used robot puppet to teach children different mathematical concepts. The robot could also be used to investigate other aspects of children's existence, such as what is meant by fairy tales, what is specific with different seasons or animals living on land and in the water (Forsberg Ahlcrona, 2012; Forsberg Ahlcrona \& Pramling Samuelsson, 2014). Using the puppet could be one way of developing the teacher's ability to interact and expand his/her communicative repertoire and contribute to creating interaction of a dialogical nature, where children use language to create meaning in a knowledgeable context.

Based on practicing and discovering a method that offers and develops interest in mathematics, many students emphasized the importance of a creative way of teaching that challenges children's mathematical thinking and actions. As a creative approach, the students specify various aesthetic expressions, partly as inspiration for the children, and partly as a support in concretizing mathematical concepts and abstractions. Aesthetic dimensions in mathematics teaching and the interaction with the robot puppet are described as rewarding and educational. For example one student describes how mathematics could be like: "I thought in the evening how to make things even more thrilling for the children."

The influence of educational and methodological implications in preschool teacher education confirms in the students analyzing documentation. Varying examples show how the students and the children develop spontaneous mathematical events as well as how they learned to communicate the mathematic language and concepts in these situations.

\section{Conflicts of Interest}

The authors declare no conflicts of interest regarding the publication of this paper. 


\section{References}

Artut, P. D. (2015). Preschool Children's Skills in Solving Mathematical Word Problems. Educational Research and Reviews, 10, 2539-2549. https://doi.org/10.5897/ERR2015.2431

Aslan, D., \& Arnas, Y. A. (2007). Three- to Six-Year-Old Children's Recognition of Geometric Shapes. International Journal of Early Years Education, 15, 83-104. https://doi.org/10.1080/09669760601106646

Bernier, M., \& O’Hare, J. (Eds.) (2005). Puppetry in Education and Therapy: Unlocking Doors to the Mind and Heart. Bloomington, Indiana: Author house.

Björklund, C. (2010). Broadening the Horizon: Toddlers' Strategies for Learning Mathematics. International Journal of Early Years Education, 18, 71-84. https://doi.org/10.1080/09669761003661246

Björklund, C., \& Pramling, N. (2014). Pattern Discernment and Pseudo-Conceptual Development in Early Childhood Mathematics Education. International Journal of Early Years Education, 22, 89-104. https://doi.org/10.1080/09669760.2013.809657

Brédikyté, M. (2000). Dialogical Drama with Puppets (DDP) as a Method of Fostering Children's Verbal Creativity. Vilnius: Vilnius Pedagogical University.

Bruner, J. (1990). Acts of Meaning. Cambridge, MA: Harvard University Press.

Carruthers, E., \& Worthington, M. (2011). Understanding Children's Mathematical Graphics. Beginnings in Play. Maidenhead: Open University Press.

Charlesworth, R., \& Leali, S. A. (2012). Using Problem Solving to Assess Young Children's mathematics Knowledge. Early Childhood Education Journal, 39, 373-382. https://doi.org/10.1007/s10643-011-0480-y

Clements, D. H., \& Sarama, J. (2007). Early Childhood Mathematics Learning. In F. K. Lester Jr (Ed.), Second Handbook of Research on Mathematics Teaching and Learning (pp. 461-555). Charlotte: Information Age Publishing.

Cross, C. T., Woods, T. A., \& Schweingrber, H. (2009). National Research Council. Mathematics Learning in Early Childhood: Paths toward Excellence and Equity. Washington DC: The National Academies Press.

Duffy, B. (2006). Supporting Creativity and Imagination in the Early Years. In V. Hurst, \& J. Joseph (Ed.), Supporting Early Learning. Maidenhead: Open University Press.

Elia, I., \& Gagatsis, A. (2003). Young Children's Understanding of Geometric Shapes: The Role of Geometric Models. European Early Childhood Education Research Journal, 11, 43-61. https://doi.org/10.1080/13502930385209161

Forsberg Ahlcrona, M. (2012). The Puppet's Communicative Potential as a Mediating Tool in Preschool Education. International Journal of Early Childhood, 44, 171-184. https://doi.org/10.1007/s13158-012-0060-3

Forsberg Ahlcrona, M., \& Pramling Samuelsson, I. (2014). Mathematics in Preschool and Problem Solving: Visualizing Abstraction of Balance. Creative Education, 5, 427-434. https://doi.org/10.4236/ce.2014.56052

Ginsburg, H. P., \& Amit, M. (2008). What Is Teaching Mathematics to Young Children? A Theoretical Perspective and Case Study. Journal of Applied Developmental Psychology, 29, 274-285. https://doi.org/10.1016/j.appdev.2008.04.008

Ginsburg, H. P., Lee, J. S., \& Boyd, J. S. (2008). Mathematics Education for Young Children: What It Is and How to Promote It. Social Policy Report, 22, 3-23.

Harris, P. L. (2000). The Work of the Imagination. Understanding Children's Worlds. Oxford: Blackwell Publishers. 
Hendy, L., \& Toon, L. (2001). Supporting Drama and Imaginative Play in the Early Years. Buckingham: Open University.

Hunt, T., \& Renfro, N. (1982). Puppetry in Early Childhood Education. Austin, TX: Renfro Studios.

Lee, J. (2005). Correlations between Kindergarten Teachers' Attitudes toward Mathematics and Teaching Practice. Journal of Early Childhood Teacher Education, 25, 173-184. https://doi.org/10.1080/1090102050250210

Lee, J. S., \& Ginsburg, H. P. (2007). What Is Appropriate Mathematics Education for Four-Year-Olds? Pre-Kindergarten Teachers' Beliefs. Journal of Early Childhood Research, 5, 2-31. https://doi.org/10.1177/1476718X07072149

Lindström, L. (2002). Learning through Art. A Research Overview. In M. Hjort, A. Unander-Scharin, C. Wiklund, \& L. Åkman (Eds.), Om konstarter och matematik $i$ lärandet: En antologi (pp. 103-132). Stockholm: Carlsson.

Linell, P. (1994). Rethinking Language, Mind, and World Dialogically. Interactional and Contextual Theories of Human Sense-Making. Charlotte, NC: Information Age Publishing.

Linell, P. (1998). Approaching Dialogue. Talk, Interaction and Contexts in Dialogical Perspectives. Amsterdam: John Benjamins Publishing Company. https://doi.org/10.1075/impact.3

Lpfö98 Läroplan för förskolan. Skolverket (2010). Curriculum for Preschool Lpfö98. Stockholm: Fritzes.

Lundin, S. (2008). Mathematics of the School. A Critical Analysis of the Swedish School Mathematical Prehistory, Origin and Development. Uppsala: Uppsala Universitet.

Lundström, M. (2015). The Quest of Preschool Children to Communicate Mathematics. Göteborg: Goteborgsuniversitet.

MacDonald, A. (2012). Young Children's Photographs of Measurement in the Home. Early Years: An International Journal of Research and Development, 32, 71-85. https://doi.org/10.1080/09575146.2011.608651

Marton, F. (1981). Phenomenography-Describing Conceptions of the World around Us. Instructional Science, 10, 177-200. https://doi.org/10.1007/BF00132516

Marton, F., \& Booth, S. (1997). Learning and Awareness. Mahwah, NJ: L. Erlbaum Associates.

Marton, F., \& Pang, M. F. (2006). On Some Necessary Conditions of Learning. The Journal of the Learning Sciences, 15, 193-220. https://doi.org/10.1207/s15327809jls1502_2

Marton, F., \& Tsui, A. B. (2004). Classroom Discourse and the Space of Learning. London: Lawrence Erlbaum Associates.

Nikiforidou, Z., \& Pange, J. (2010). The Notions of Chance and Probabilities in Preschoolers. EarlyChildhood Education Journal, 38, 305-311.

Palmer, A. (2011). How to Become a Mathematical? Creating New Relationships to Mathematics and Gender in Work with Younger Children. Stockholm: Liber.

Pavlovičová, G., \& Švecová, V. (2011). Children's Drawings-Resource for Development and Observation of Perception of Numbers of Children. Acta Didactica Napocensia, 4, $1-8$.

Pramling, I. (1990). Learning to Learn. A Study of Swedish Preschool Children. New York, NY: Springer-Verlag. https://doi.org/10.1007/978-1-4612-3318-3

Pramling, I. (1996). Understanding and Empowering the Child as a Learner. In D. Olson, \& N. Torrance (Eds.), Handbook of Education and Human Development: New Models 
of Learning, Teaching and Schooling (pp. 565-589). Oxford: Basil Blackwell.

Säljö, R. (2005). Learning \& Cultural Tools. About Learning Processes and Collective Memories. Stockholm: Norstedts Akademiska Förlag.

Sandahl, A. (2010). Mathematics as Art or Art as Mathematics. In E. Alerby, \& J. Elídóttir (Eds.), The Art of Learning-Contemplations of the Aesthetical Dimensions of Learning (pp. 87-102). Lund: Studentlitteratur.

Sarama, J., \& Clements, D. H. (2009). Early Childhood Mathematics Education Research. New York: Taylor \& Francis.

Wernberg, A. (2009). The Object of Learning - What Pupils Are Expected to Learn, What Is Made Possible for Them to Learn and What They Actually Are Learning during the Lessons (p. 32). Umeå och Kristianstad: Umeå universitet och Högskolan Kristianstad. Doktorsavhandlingar i pedagogiskt arbete.

Wertsch, J. (2002). Voices of Collective Remembering. Cambridge: Cambridge University Press. https://doi.org/10.1017/CBO9780511613715

Zacharos, K., Antonopoulos, K., \& Ravanis, K. (2011). Activities in Mathematics Education and Teaching Interactions. The Construction of the Measurement of Capacity in Preschoolers. European Early Childhood Education Research Journal, 19, 451-468.

https://doi.org/10.1080/1350293X.2011.623520 